\section{Frank Press to head new inquiry into US science policy}

Washington. Frank Press, former president of the National Academy of Sciences and before that President Jimmy Carter's science adviser, is to lead a major inquiry into how the federal government allocates research and development (R\&D) money in the United States.

The study will begin next month and is due to be completed in December 1995. According to Press, it will consider all federal R\&D spending - which totalled $\$ 73$ billion this year - except for the large amounts spent on the development and trials of military equipment.

The report was requested by the Senate's labour, health and human services and education appropriations subcommittee, chaired by Tom Harkin (Democrat, Iowa), in a recent budget bill. Press says that its scope will be more comprehensive than any other undertaken in recent years.

"It is an extraordinary opportunity," he says, adding that the exercise "could have the impact of a Vannevar Bush report", a reference to the influential report Science: The Endless Frontier that laid the basis of US science policy after the Second World War.

Members of the panel are being selected, and will be announced next month. The panel will function

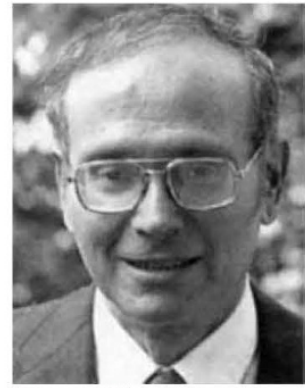

Press: 'Could have impact of Bush report' under the auspices of the National Research Council, the research arm of the National Academies of Science and Engineering and the Institute of Medicine.

The Senate subcommittee, which is providing $\$ 750,000$ to pay for the study, said it was worried that funding for medical research is growing more slowly than the rate of inflation. "The study should consider the criteria that should be used in judging the appropriate allocation of funds to research and development activities," it said.

The work of the panel is likely to have a big impact not just on biomedical research - Harkin's main area of interest - - but across the entire federal $R \& D$ programme. Many policy-makers feel that the priorities of the vast programme have been left badly out of date by the ending of the Cold War.

A recent OSTP science policy report Science in the National Interest (see Nature 370,5 ; 1994) — made the case for basic science. But it did not deal with the more difficult area of setting new R\&D priorities for the nation.

Colin Macilwain

\section{US to use science links to meet foreign policy goals}

Washington. President Bill Clinton's administration has selected six countries Russia, China, India, South Africa, Argentina and Brazil - with which it will seek to secure foreign policy goals through collaboration in science and technology. One possible model is the recent agreement to involve Russia in the international space station.

Jane Wales, assistant director for national security and international collaboration at the White House Office of Science and Technology Policy (OSTP), revealed the strategy to an advisory panel of scientists and industrialists, which met for the first time in Washington last week.

Some members of the panel - the President's Council of Advisors on Science and Technology (PCAST) - expressed reservations about the durability of such collaborations and their impact on US employment.

Wales said that each of the six countries was chosen on three criteria: that each had had a real or potential nuclear capability; that each was going through a period of political transition; and that each offered major potential markets for US exports. "We believe we can apply science and technology collaboration to building stability" in these countries, she said.

According to Wales, the administration has already conducted fact-finding missions to four of the six countries. But further details of the approach remain vague. The international space station collaboration with Russia is one model, officials say, and a science and technology collaboration deal due to be signed with China next month will provide another.

\section{Scientists support expelled researcher}

Paris. Over 4,000 French scientists have signed a petition in support of Abderrahmane Bahri, an Algerian national and an engineer at the Centre National de la Recherche Scientifique (CNRS), who was imprisoned in Folembray army barracks in August and later expelled from France for allegedly having links with terrorist groups in Algeria.

Charles Pasqua, the minister of the interior, expelled Bahri using the "absolute emergency act" which allows the government to bypass the usual judicial procedures on the ground of state security.

The expulsion order accuses Bahri of "actively supporting in Europe the forwarding and distribution of material destined for armed groups in Algeria". Bahri, it says, has "numerous links" with senior official with extensive experience of previ-

members of terrorist organizations, and posed a "threat to national security and public safety".

But Bahri's colleagues at the CNRS National Synchrotron Facility (LURE) at Orsay near Paris, have formed a "committee of solidarity" to secure both his return to France, and the right to answer the charges against him in a normal judicial hearing. Paris XI at Orsay and the 'Comité Paritaire' of CNRS have passed similar motions, while the 'Comité de Defense des Hommes de Science' of the French Academy of Sciences - chaired by the Nobel prizewinner François Jacob - and the Human Rights Commission of the French Physical Society have written to Pasqua with the same request. Declan Butler
Officials concede that building public support and obtaining funds from Congress for such collaborations will not be easy. David Shaw, for example, a member of PCAST who helps finance technology-based companies, said that the approach was likely to "result in the export of a large number of jobs of the very kind we most want to keep".

Charles Vest, president of the Massachusetts Institute of Technology (MIT) - citing the destruction of MIT's work with Japan before the Second World War -suggested that US institutions may be reluctant to work too closely, or too publicly, with some of the countries on the list.

The first meeting of PCAST, longdelayed since its announcement more than a year ago, had some difficulty in establishing a coherent agenda. After a wide-ranging discussion, the panel, which is co-chaired by John Young, former president of HewlettPackard, and Jack Gibbons, science adviser to Clinton, agreed to confine itself chiefly to reviewing strategy documents produced by the nine subpanels of the administration's National Science and Technology Council.

Vice president Al Gore met the panel. before its meeting, but left no clear message of what he wanted its members to do.

David Beckler, a former White House ous such panels, told the meeting that "receptivity" - an assurance that the president wanted your advice - was a requisite for success, quoting for example the need to provide information about surprise nuclear attacks. Without such receptivity, he warned, the work of such panels was "just an intellectual tennis game".

Colin Macilwain
Both the board of the University of 